\title{
Pengaruh Pemanfaatan E-learning Terhadap Motivasi Belajar Mahasiswa
}

\author{
Dimas Anditha Chyo Sujiwo', Qurrota A'yun² \\ ${ }^{1}$ IKIP PGRI Jember, ${ }^{2}$ Universitas Muhammadiyah Jember \\ 1'cahyodimas10@gmail.com, ${ }^{2}$ qurrota.ayun@unmuhjember.ac.id
}

(Naskah Masuk: 5 Mei 2020, diterima untuk diterbitkan: 12 Mei 2020)

\begin{abstract}
Abstrak:
E-learning merupakan peroses pembelajaran yang memanfaatkan kecanggihan suatu teknologi yang mana dalam proses pembelajarannya dilakukan secara online. pembelajan online terdapat tools yang dapat dimanfaatkan oleh mahasiswa maupun Dosen dalam kegiatan Pembelajaran seperti kegiatan komunikasi dan interaksi, melakukan kegiatan pemberiaan pertanyaan, bertanya kepada Dosen atau sebaliknya, dan menanggapi pernyataan dari teman-temannya. Dengan adanya tools yang lengkap ini akan memberi kenyamanan kepada Dosen dan mahasiswa dalam pembealajran. Kegiatan yang dilakukan tentunya dapat mengurangi rasa jenuh bagi mahasiswa sehingga motivasi belajarnya meningkat. Berdasarkan hasil penelitian menunjukkan terdapat pengaruh pembelajaran e-learning terhadap motivasi belajar mahasiswa. Hal tersebut ditunjukkan dengan nilai signifikansi sebesar 0,000 yang kurang dari 0,05 dan nilai t-hitung yang lebih besar dari t-tabel sebesar 11,737 > 2.02439. berdasarkan $R$ Square menunjukkan bahwa motivasi belajar mahasiswa dipengaruhi sebesar $77,3 \%$ dalam penelitian ini dan sebesar $22,7 \%$ dipengaruhi oleh variabel dari luar penelitian.
\end{abstract}

Kata Kunci: E-learning, Motivasi Belajar.

\begin{abstract}
E-learning is a learning process that utilizes the sophistication of a technology which in the learning process is done online. Online learning there are tools that can be used by students and lecturers in learning activities such as communication and interaction activities, conducting questions, asking lecturers or vice versa, and responding to statements from friends. With this complate tools, it will provide comfort for students and lecturers in the teaching and learning process. The activities carried out certainly can reduce boredom for students so that their motivation to learn increases. Based on the results of the study indicate there is an influence of e-learning on student motivation. This is indicated by the significance value of 0,000 which is less than 0,05 and the $t$-test value greather than $t$-table of $11,737>2,02439$. Based on $R$ Square shows that student motivation is influenced by $77,3 \%$ in this study and $22,7 \%$ is influenced by variables from outside the study.
\end{abstract}

Keywords: E-learning, Learning Motivation.

\section{PENDAHULUAN}

Wabah Covid-19 yang terjadi hari ini memaksa seluruh masyarakat menjalani kehidupan yang berbeda pada umumnya. Dimana dalam kehidupan bermasyarakat terdapat aturan-aturan yang perlu dilakukan untuk mencegah wabah covid-19 meluas. Masyarakat perlu mengubah dan p-ISSN : 2502-5724; e-ISSN : 2541-5735 membiasakan dengan dengan adanya aturan-aturan seperti sering-sering mencuci tangan dan menggunakan hand sanitixer, menggunakan masker setiap keluar rumah, dan sebagainya. Kebiasaan yang dilakukan dalam masyarakat ini akibat pandemi covid-19 ini juga berimbas dalam dunia pendidikan. Pendidikan yang 
menjadi tonggak kemajuan suatu bangsa harus selalu diperhatikan oleh pemerintah dan jajarannya. Sehingga, dunia pendidikan tetap berjalan dan berkembang walaupun dalam keadaan pandemi covid19.

Persiapan dalam menjalankan berbagai kegiatan pendidikan seperti membimbing peserta didik untuk mengembangkan ketrampilannya sangat dibutuhkan di masa pandemi covid 19 ini. Alasan utamanya adalah pendidikan sabagai peranan yang besar dalam meningkatkan dan mengembangkan sumber daya manusia. Pendidikan juga berpotensi menjadikan SDM yang tangguh dan mandiri, serta berdaya saing di dimasa yang akan datang. Yang terjadi pada pendidikan hari ini tentu akan mengalami kesulitan dalam berbagai hal. Kegiatan belajar mengajar yang sering dilakukan tentunya perlu suatu terobosan dimana peserta didik dapat belajar dengan baik sebagaimana mestinya.

Di era globalisasi yang modern saat ini dimana setiap teknologi selalu ada dalam kehidupan sehari-hari, menjadikan kita mudah dalam melakukan sesuatu hal. Kecanggihan teknologi ini perlu kita manfaatkan dalam kegiatan pendidikan di masa pandemi covid 19. Dengan dibatasinya kehidupan sosial, maka seyogyanya kita memanfaatkan teknologi untuk kegiatan belajar mengajar. Belajar online atau yang sering kita sebut $e$ learning adalah peroses pemanfaatan kecanggihan suatu teknologi yang mana dalam proses pembelajarannya dilakukan secara online. Hal ini sesuai dengan pendapat Soekarwati (2003) yang mendefinisikan e-learning sebagai berikut: "E-learning is sebuah istilah umum untuk pembelajaran yang didukung suatu teknologi menggunakan alat belajar sebagai penghubung seperti telpon, audio, konferensi jarak jauh, serta pelatihan yang berbasis web sebagai bantuan komputer".
Uraian tersebut menjelaskan bahwa dalam kegiatan pembelajan online terdapat tools yang dapat dimanfaatkan peserta didik maupun pendidik dalam hal komunikasi dan interaksi, serta dapat melakukan kegiatan pemberiaan pertanyaan, bertanya, dan menanggapi pernyataan dari teman-temannya. Dengan adanya tools yang lengkap ini akan memberi kenyamanan kepada pelaku pembelajaran. Kegiatan ini dilakukan tentunya mengurangi rasa jenuh yang tidak dilakukannya pemebelajaran tatap muka. Dalam kemajuan teknologi hari ini tentunya memungkinkan peserta didik untuk belajar sepenuhnya secara online dengan menjalin komunikasi sesama teman sekelas, memperhatikan dan menonton kuliah, serta ikut berpartisipasi dalam diskusi khusus mata pelajaran yang diampunya.

Sebagai salah satu Perguruan Tinggi yang memanfaatkan kecanggihan teknologi, IKIP PGRI Jember memanfaatkan dan menggunakan $e$ learning sebagai proses belajar mengajar. Dalam penggunaannya, Dosen dan mahasiswa melakukan kegiatan diskusi dalam kegiatan belajar mengajar, serta dalam pembeerian informasi terkait materi perkuliahan, tugas-tugas yang akan diberikan kepada mahasiswa, quiz yang perlu dikerjakan, serta kegiatan -kegiatan tugas-tugas kelompok. Dengan adanya $e$ learning di lingkungan IKIP PGRI Jember, tentunya bertujuan untuk menambah motivasi mahasiswa dalam proses pembelajaran. Dengan meningkatnya motivasi belajar mahasiswa, diharapkan dapat berdampak besar terhadap prestasi belajar mahasiswa secara keseluruhan. Mahasiswa juga disediakan modul yang telah dibuat oleh dosen, yang diharapkan dapat menambah motivasi belajar mahasiswa juga. Learning resources disebut segala sesuatu yang dapat membantu terjadinya proses pembelajaran. Sumber belajar yang ada dapat 
mempermudah mahasiswa dalam mencapai tujuan belajar. Sumber belajar juga dapat meningkatkan suatu interaksi dan terjadinya umpan balik dengan mahasiswa.

Pembelajaran online yang dimanfaatkan di lingkungan IKIP PGRI Jember, tentunya mengharapkan seluruh kegiatan proses pembelajaran dapat dilaksanakan dengan maksimal dan motivasi belajar mahasiswa dapat bertambah dengan adanya sistem eleaning. Menurut Novak (dalam Balaji, AlMahri, \& Malathi, 2016) penggunaan elearning dalam kegiatan pembelajaran

Memudahkan dan meningkatkan jalannya pembelajaran seperti hal interaksinya dan efisiensinya, komunikasi antara mahaiswa dan dosen pun akan lebih tinggi. Serta akses materi belajar mudah. Ketertarikan dan motivasi belajar mahasiswa akan menjadi kunci dan tolak ukur bahwasanya e-learning merupakan media pembelajaran yang memiliki manfaat bagi mmahasiswa pada umumnya. Menurut Yamin (2009:174) Sesuatu informasi yang disampaikan dengan teknik yang baru, dengan kemasan yang bagus didukung oleh alat-alat berupa sarana atau media yang belum pernah dikenal oleh siswa sebelumnya sehingga menarik perhatian bagi mereka untuk belajar. Oleh karena hal itu, baik dosen sebagai pendidik maupun mahasiswa bermotivasi dalam belajar. Dengan adanya motivasi dalam belajar, maka proses belajar segala informasi yang disampaikan akan berpotensi besar dapat diterima oleh mahasiswa.

Motivasi berarti menggerakkan sesuatu dalam diri seseorang. motivasi merupakan sesuatu hal yang dapat menyebabkan seseorang melakukan tindakan atau perilaku untuk mencapai tujuan atau sesuatu yang diharapkan. Menurut Uno (2011: 23) motivasi belajar adalah dorongan internal dan eksternal untuk mengadakan perubahan tingkah laku, pada umumnya dengan beberapa indikator atau unsur yang mendukung. motivasi dapat dikatakan sebagai daya penggerak atau pendorong dari seseorang untuk melakukan pekerjaannya, yang mana dalam diri seseorang ini akan timbul reaksi belajar untuk mencapai suatu tujuan.

Motivasi belajar dalam penelitian ini adalah model motivasi ARCS. Model Motivasi ARCS terdiri dari empat kompoenen: attention, relevance, confidance, and satisfaction. menurut Chang dan Chen (2015) model motivasi ARCS yang terdiri dari attention, relevance, confidance, and satisfaction adalah model yang saling berhubungan dalam membuat pedoman motivasi pembelajaran. Hubungan antara keempat komponen model motivasi ARCS dengan pembelajaran e-learning adalah sebagai berikut.

Attention adalah aktivitas untuk mengatahui adanya peningkatan keinginantahuan mahasiswa. Relevance untuk mengetahui adanya relevansi dengan kebutuhan mahasiswa. Komponen ketiga yaitu kepercayaan (confidence), kegiatan pembelajaran online ini apakah dapat meningkatkan kepercayaan diri mahasiswa, dan komponen keempat yaitu kepuasan (satisfaction), yang digunakan apakah aktivitas pemebelajaran online membawa kepuasan pada mahasiswamahasiswanya.

Penjelasan terkait masing-masing komponen dari motivasi belajar adalah sebagai berikut: 1) attention, munculnya perhatian dari sesorang dapat karena suatu keinginantahuan yang yang baru. Dalam hal ini pembelajaran e-learning merupakan pembelajaran yang baru bagi mahasiswa yang mana dalam e-learning terdapat tools yang dapat digunakan untuk merangsang dan meningkatkan perhatian mahasiswa dalam proses pembelajaran online; 2) relevance, kebutuhan yang 
ditunjukkan antara proses pembelajaran online dengan mahasiswa. Dengan penggunaan pembelajaran online ini mahasiswa akan memiliki motivasi yang tinggi, hal tersebut dilakukan dengan pembuatan sumber belajar yang interaktif sehingga maahsiswa dapat berinteraksi satu sama lain dan fantasi dalam mencapai tujuan pembealajran; 3) confidence, mampu berinteraksi dengan lingkungannya berakibat pada kepercayaan. Mahasiswa dapat salng berinteraksi dengan pemberian pendapat dan umpan balik, dengan adaya stimulus yang beragam motivasi mahasiswa timbul dalam rasa percaya diri mahasiswa tersebut; 4) satisfaction, perasaan senang dan positif dalam melakukan kegiatan pembelajaran dengan sistem e-learning. Mahasiswa memiliki kesempatan belajar seluas-luasnya. Materi yang telah disediakan oleh dosen bukan satu-satunya materi yang diperoleh mahasiswa. Mahasiswa berkesampatan memperoleh materi sebanyak-banyaknya dan seluasnya dengan cara berseluncur di dunia internet. Mahasiswa juga dapat seluas-luasnya dalam melakuakan kegiatan pemberian pertanyaan dan respon (umpan balik). Dengan pembelajaran online ini tentunya memberikan dampak yang positif bagi mahasiswa dalam proses belajar yang baru yang membangkitkan motivasi mahasiswa masing-masing. Penggunan pembelajaran e-learning terhadap mahasiswa di IKIP PGRI Jember ini dapat diajadikan pendorong dalam meningkatkan dan membangkitkan motivasi mahasiswa.

\section{METODE PENELITIAN}

Penelitian ini dilaksanakan di IKIP PGRI Jember dengan subjek penelitian adalah mahasiswa FP MIPA IKIP PGRI Jember. Teknik analisis data menggunakan teknik analisis kuantitatif. Pengolahan data melalui angket, untuk mengukur setiap variabel, yaitu variabel yang tidak terikat yaitu pembelajaran e-learning dan variabel terikat yaitu motivasi mahasiswa.

Menurut pendapat Augusty (2014) bahwa sampel cukup valid untuk dianalisis secara statistik sedikitnya diperlukan 30 sampai 100 responden. Berdasarkan pendapat Augusty tersebut, maka sampel responden mahasiswa dalam penelitian ini adalah 40 responden yaitu mahasiswa FP MIPA IKIP PGRI Jember. Hal ini dikarenakan peneliti mengambil responden yang mengalami kegiatan proses pembelajaran e-learning dalam setiap minggunya. Responden ini merupakan mahasiswa dengan jurusan pend. matematika dan jurusan pend. biologi.

Dalam pengumpulan data berupa angket dari responden, selanjutnya dilakukan pengujian validitas dan reliabilitas pada angket tersebut. Pengujian ini dilakukan di angket yang berjumlah 40 buti soal, dengan 23 butir soal tentang pembelajaran e-learning dan 17 soal butir soal tentang motivasi belajar mahasiswa. Penggunaan pengujian ini menggunakan program SPSS dengan statistics 26 , diperoleh 13 pertanyaan valid dan 10 pertanyaan tidak valid untuk pembelajaran e-learning serta 8 pertanyaan valid dan 9 pertanyaan tidak valid untuk variabel motivasi belajar mahasiswa. Sehingga dengan adanya hasil ini, maka soal yang akan diberikan kepada responden sebanyak 13 butir soal dari pembelajaran e-learning dan 8 butir soal dari motivasi belajar mahasiswa.

Angket dapat diyatakan valid disaat yang di ukur atau dalan statistikanya nilai $r$ hitung ini lebih besar dari nilai $r$-tabel dan bernilai positif, sementara reliabelitas digunakan untuk mengetahui kekonsistenan dari sebuah pertanyaan. Apabila suatu variabel bernilai lebih besar dari 60 Cronbach-Alphanya (a) maka dikatakan reliabel, sementara sebalikanya tidak reliabel apabila Cronbach-Alphanya (a) nilainya kurang dari 60 . Sementar untuk 
hipotesis penelitian berdasar variabel penelitian yang digunakan, maka hipotesis penelitian yaitu $\mathrm{H}_{1}$ : Pembelajaran $e$ learning berpengaruh terhadap motivasi belajar mahasiswa dan $\mathrm{H}_{0}$ : Pembelajaran e-learning tidak berpengaruh terhadap motivasi belajar mahasiswa.

Berikut dijabarkan alur penelitian ini: 1) melakukan studi literatur; 2) pembuatan instrumen pengukuran yang berupa angket atau quisioner; 3) pemberian atau penyebaran angket kepada subjek peneltian yaitu mahasiswa FP MIPA IKIP PGRI Jember yang terdiri dari program studi pendidikan matematika dan pendidikan biologi; 4) pelaksanaan analisis data dengan cara melakukan pengumpulan angket dan menganalisisnya datanya dengan statistik kuantitatif; 5) terakhir dilakukan penarikan hasil kesimpulan.

\section{HASIL DAN PEMBAHASAN}

Analisis data terhadap kuisioner, perhitungan validitas butir soal dengan SPSS, pembelajaran e-learning terdapat 13 butir soal yang valid dan 8 butir soal yang tidak valid sementara motivasi belajar mahasiswa diperoleh 8 butir soal yang valid dan 9 butir soal tidak valid. Dengan validitas tersebut, maka peneliti menggunakan seluruh butir soal yang valid dijadikan bahan penelitian. Sementara dalam penhitungan nilai reliabilitas menggunakan SPSS bahwa nilai cronbach Alpha bernilai 0.976 yang mana lebih dari 0,6 yang memiliki arti bahwa data tersebut reliabel. Peneliti dalam menghitung data statistics menggunakan IBM SPSS Statistics 26. Berikut nilai reliabel yang diperoleh.

\begin{tabular}{|c|c|}
\hline \multicolumn{2}{|c|}{ Reliability Statistics } \\
\hline $\begin{array}{c}\text { Cronbach's } \\
\text { Alpha } \\
\end{array}$ & $\mathrm{N}$ of Items \\
\hline ,976 & 21 \\
\hline
\end{tabular}

Uji syarat, peneliti melakukan uji yang namanya uji normalitas, uji linieritas, dan uji homogenitas. uji normalitias, peneliti menggunakan uji kolmogorov smirnov. Dalam pengambil keputusan dalam uji kolmogorov smirnov ini nilai residual adalah berdistribusi normal apabila nilai signifikansi lebih dari 0,05. Berikut nilai hitung menggunakan SPSS.

One-Sample Kolmogorov-Smirnov Test

\begin{tabular}{llr} 
& & \multicolumn{1}{c}{$\begin{array}{r}\text { Unstandardized } \\
\text { Residual }\end{array}$} \\
\hline $\mathrm{N}$ & Mean & 40 \\
\hline Normal & Std. Deviation &, 0000000 \\
Parameters $^{\text {a,b }}$ & Absolute &, 128 \\
\hline Most Extreme & Ab414117 \\
\cline { 2 - 3 } Differences & Positive &, 090 \\
\cline { 2 - 3 } & Negative &,- 128 \\
\hline Test Statistic & &, 128 \\
\hline Asymp. Sig. (2-tailed) &, $097^{c}$ \\
\hline
\end{tabular}

Berdasarkan uji kolmogorovSmirnov diperoleh nilai signifikansi sebesar $0,097>0,05$, maka nilai residual dikatakan berdistribusi normal.

Dala uji linieritas peneliti menggunakan tes liniertias dalam annova table,yang mana nilai variabel bebas dan nilai variabel terikat memiliki hubungan linier apabila nilai sign. > 0.05. setelah dilakukan uji, sign. Deviation from linearity sebesar 0,532 > 0,05 maka terdapat hubungan antara nilai variabel bebas dengan nilai variabel tidak bebas.

\begin{tabular}{|c|c|c|c|c|}
\hline $\begin{array}{l}\text { Sum of } \\
\text { Squares }\end{array}$ & $d f$ & Mean Square & $F$ & Sig. \\
\hline 1094,740 & 14 & 78,196 & 9,220 &, 000 \\
\hline 991,262 & 1 & 991,262 & 116,873 &, 000 \\
\hline 103,478 & 13 & 7,960 &, 938 &, 532 \\
\hline
\end{tabular}


sebesar 0,148. Yang mana berdasarkan pengambilan keputusan apabila nilai signifikansi $>0,05$ maka distribusi data homogen. Karena nilai signifikansi data $0,148>0,05$ artinya berdistribusi data homogen. Berikut nilai data menggunakan SPSS dengan uji levene statistic.

\begin{tabular}{c|r|r|r}
$\begin{array}{l}\text { Levene } \\
\text { Statistic }\end{array}$ & df1 & df2 & Sig. \\
\hline 2,140 & 1 & 78 &, 148 \\
\hline
\end{tabular}

Berdasarkan hasil pengujian regresi linear sederhana dapat dilihat dari hasil output Coefficients berikut ini.

\begin{tabular}{|c|c|c|c|c|}
\hline \multicolumn{5}{|c|}{ Coefficients $^{a}$} \\
\hline \multicolumn{2}{|c|}{ Unstandardized Coefficients } & $\begin{array}{c}\text { Standardized } \\
\text { Coefficients }\end{array}$ & & \\
\hline B & Std. Error & Beta & $t$ & Sig. \\
\hline 1,593 & 2,155 & &, 739 &, 464 \\
\hline 685 &, 060 & 879 & 11,373 &, 000 \\
\hline
\end{tabular}

Data uji SPSS tersebut menunjukkan bahwa terdapat nilai konstanta sebesar 1,593 yang artinya apabila pembelajaran e-learning sebesar 1,593 maka motivasi belajar mahasiswa sebesar 1,593 . Selanjutnya nilai koefisien regresi variabel 0,685 yang artinya apabila setiap peningkatan pembelajaran $e$ learning sebesar 0,685 maka motivasi belajar mahasiswa juga meningkat sebesar 0,685 . Sementara dalam uji $t$ yang penghitungannya menggunakan IBM SPSS Statistics 26, t-hitung sebesar 11,373 dan signifikansi 0,000 . Sementara untuk t-tabel dengan kebebasan (df) $n-2$, sehingga 40 $2=38$, maka nilai yang didapatkan sebesar 2,02439. Karena berdasarkan kriteria pengujian dan kriteria signifikansi yang mana jika nilai $\mathrm{t}_{\text {-hitung }}$ lebih besar dari $\mathrm{t}_{\text {-tabel }}$ yaitu $(11,737>2.02439)$ dan nilai signifikansi $(0,000<0,05)$ maka $\mathrm{H}_{0}$ ditolak dan $\mathrm{H}_{1}$ diterima. Dengan begitu kesimpulan yang ada adalah Pembelajaran e-learning 58 berpengaruh terhadap motivasi belajar mahasiswa.

\begin{tabular}{ll|r|r|r}
\multicolumn{7}{c}{ Model Summary } \\
Model & R & R Square & $\begin{array}{c}\text { Adjusted R } \\
\text { Square }\end{array}$ & $\begin{array}{c}\text { Std. Error of } \\
\text { the Estimate }\end{array}$ \\
\hline $1 \quad$ &, $879^{\text {a }}$ &, 773 &, 767 & 2,810 \\
\hline \multicolumn{3}{l}{ a. Predictors: (Constant), Religiusitas }
\end{tabular}

Selanjutnya berdasarkan hasil $R$ Square, nilai $R$ adalah 0,879 dan nilai dari koefisien determinasi atau yang disebut $R$ Square sebesar 0,773 . Nilai tersebut menunjukkan bahwa motivasi belajar mahasiswa dipengaruhi sebesar $77,3 \%$ dan dipengaruhi oleh variabel lain dari luar penelitian sebesar $22,7 \%$.

\section{PENUTUP \\ KESIMPULAN}

Hubungan yang positif antara pembelajaran e-learning dengan motivasi belajar mahasiswa. Hal ini dikarenakan nilai signifikansi sebesar $0,000<0,05$ dan nilai $\mathrm{t}_{\text {-hitung }}>\mathrm{t}_{\text {-tabel }}$ sebesar 11,737 > 2.02439. berdasarkan $R$ Square menunjukkan bahwa motivasi belajar mahasiswa dipengaruhi sebesar $77,3 \%$ dalam penelitian ini dan sebesar 22,7\% dipengaruhi oleh variabel dari luar penelitian.

\section{Daftar Pustaka}

Augusty, F. 2014. Metodologi Penelitian. Undip Press. Semarang.

Balaji, R., Al-Mahri, F., \& Malathi, R. 2016. A Perspective Study on Content Management in E-Learning and M-Learning. eprint arXiv:1605.02093. Retrieved from http://arxiv.org/abs/1605.02093

Chang, N. C., and Chen, H. H. 2015. "A motivational analysis of the ARCS model for information literacy courses in a blended learning environment", Libri, 65(2), 129-142. 
JUSTINDO (Jurnal Sistem \& Teknologi Informasi Indonesia), Vol. 5, No. 2, Agustus 2020

Soekartawi. 2003. Prinsip Dasar eLearning: Teori dan Aplikasinya di Indonesia. Jurnal Teknodik, Edisi Vol 7 No.12.

Uno, H. 2011. Teori Motivasi dan Pengukurannya: Analisis di Bidang Pendidikan. Jakarta: Bumi aksara.

Yamin, H. M. 2009. Srategi Pembelajaran Berbasis Kompetensi. Jakarta: Gaung Persada. 